\title{
Bauran Pemasaran Wisata Agro Salak Pondoh Organik di Dusun Ledoknongko, Desa Bangunkerto, Kecamatan Turi, Kabupaten Sleman
}

Fransiskus Renaldo Hoya a, 1 Dian Pramita Sugiarti a, 2

${ }^{1}$ aldoehoya98@gmail.com²dian_pramita@unud.ac.id

a Program Studi Sarjana Destinasi Pariwisata, Fakultas Pariwisata, Universitas Udayana, Jl. Dr. R. Goris, Denpasar, Bali 80232 Indonesia

\section{Abstract}

This research is located at Wisata Agro Salak Pondoh Organik Ledoknongko (WASPOL), Bangunkerto Village that is one of the agritourism in Sleman District, Yogyakarta. The background of the research includes a variety of activity options in WASPOL, Salak Pondoh as a profitable commodity, and there is government support to preserve organic Salak Pondoh varieties. The tourist activities options in WASPOL is about cultivation, enjoy picking the salak and also processing the fruits into any other product in traditional way. Salak Pondoh is a profitable commodity because it can export in large quantities.

The objective of this research is to identify the profile of tourists and marketing mix of WASPOL. The data is collected through interviews and observation. The informants are determined by purposive sampling technique. The data is analyzed qualitatively through the process of data reduction, display, and drawing/verification.

The results of the study show that, the profile of tourists visiting WASPOL have the same purpose which is to conduct research, this is because there are researchers from various Universities and Schools in Indonesia. Tourists will also be taught how to cultivate Salak Pondoh by Farmers and can immediately pick and eat Salak fruit. The rate of tourists visits has decreased, from 2015 amounted to 3,493 visitors dropped to 2,523 visitors in 2016 with a percentage decrease of 72\%, while in 2017 there were 1,278 visitors with a percentage decrease of 50\%. The decline in tourist arrivals from 2015-2017 because WASPOL is more focused on the export of Salak Pondoh fruit. The results of the marketing mix analysis at WASPOL are where WASPOL exports Salak Pondoh to various countries such as China, Australia and Cambodia while salak processed products are only sale in souvenir shops in Yogyakarta. The price of salak exported is Rp. 50,000/Kg, while for salak fruit for sale in plantation areas for Rp. 20,000/basket. Salak Pondoh production process is carried out at the home of the farmers' groups and all who carry out cultivation activities and salak marketing are people who come from Sub Ledoknongko. Salak plantations are neatly arranged and clean from rubbish. WASPOL is promoted through their official blog, sicantikledoknongko.blogspot.com. There are several recommendation to the management of WASPOL as follow: to add the facilities like toilet and signboard, promoting on social media, and if possible make a website that explains about WASPOL and existing tour packages.

Keywords: Tourist Profile, Marketing Mix, Agritourism, Salak Pondoh, Ledoknongko Village

\section{PENDAHULUAN}

Perkembangan pariwisata di Indonesia terutama di beberapa daerah seperti Yogyakarta dan Bali sudah pesat. Pariwisata bahkan sudah menjadi andalan ekonomi pembangunan daerah. Perkembangan pariwisata seperti di Bali dan Yogyakarta (termasuk beberapa daerah yang telah memiliki riwayat panjang pariwisata) akan terus berevolusi (Mahagangga, dkk., 2019).

Daerah Istimewa Yogyakarta, sebagai kota pendidikan dan kota perjuangan juga sangat mengandalkan sektor pariwisata. Saat ini, sektor pariwisata juga menjadi andalan bagi Daerah Istimewa Yogyakarta. Hampir semua kabupaten dan kota di Daerah Istimewa Yogyakarta mempercepat pembangunan fasilitas penyokong pariwisatanya. Hal ini dilakukan dengan maksud untuk kelancaran dan peningkatan sektor pariwisata, serta menjadi bukti bahwa pemerintah dan masyarakat serius dalam mengembangkan sektor ini. Daerah Istimewa Yogyakarta terdiri atas empat kabupaten (Bantul, Gunungkidul, Kulonprogo, Sleman) dan satu kota (Yogyakarta), yang di setiap kabupaten dan kotanya sudah tersebar beberapa daya tarik wisata.

Adapun daya tarik wisata menarik yang terletak di Kabupaten Sleman adalah Wisata Agro Salak Pondoh Organik Ledoknongko yang terletak di Dusun Ledoknongko, Desa Bangunkerto, Turi, Sleman, sekitar $20 \mathrm{~km}$ atau dapat ditempuh dalam waktu 30 menit dari pusat Kota Yogyakarta. Wisata Agro Salak Pondoh Organik Ledoknongko (WASPOL) memiliki lahan seluas 8 hektar dan berada di ketinggian $200 \mathrm{mdpl}$ yang ditanami sekitar 17 jenis salak. Beberapa diantaranya adalah Salak Pondoh Super, Salak Pondoh Kuning, Salak Pondoh Hitam, Salak Gading, Salak Madu, Salak Pondoh Merah, 
Salak Pondoh Manggala, Salak Pondoh Gula Pasir, Salak Pondoh Klinting, Salak Bali, Salak Tanonjaya, Salak Semeru, Salak Petruk, Salak Nangka, Salak Bangkok, Salak Doyong Dan Salak Manggada. WASPOL juga membudidayakan tanaman obat seperti jahe, temulawak, kencur, kunci, sirih. Salak yang dimiliki WASPOL juga sudah berbasis organik yang tentunya sehat untuk dikonsumsi. Kawasan WASPOL juga merupakan wilayah yang khusus karena merupakan bagian dari upaya pemerintah dalam melestarikan flora yang ada di Sleman.

Menikmati pemandangan areal perkebunan salak yang luas dan sejuknya udara khas pegunungan, ada beberapa aktivitas lain yang dapat dilakukan oleh wisatawan di WASPOL diantaranya adalah belajar mengenai budi daya tanaman salak mulai dari proses penanaman benih hingga proses memanen yang dipandu oleh ahlinya, memetik Salak Pondoh langsung dari pohonnya, melihat pengolahan salak secara tradisional. WASPOL oleh kelompok Tani Si Cantik menyediakan beberapa fasilitas yang menarik untuk mendatangkan wisatawan dan tentunya memudahkan wisatawan. Melihat antusias dan hal-hal menarik yang dilakukan di WASPOL oleh pengelola, peneliti melakukan penelitian untuk menganalisa tentang profil wisatawan di Wisata Agro Salak Pondoh Organik Ledoknongko dan bauran pemasaran Wisata Agro Salak Pondoh Organik Ledoknongko, Desa Bangunkerto, Kecamatan Turi, Kabupaten Sleman.

\section{LANDASAN KONSEP}

Landasan konsep/teori yang digunakan dalam penelitian ini yakni Wisata Agro (Hibran, 2016) dan Bauran Pemasaran $7 P$ (Kotler dan Amstrong (2012:62).

\section{III.METODE PENELITIAN}

Penelitian ini mengambil lokasi di Wisata Agro Salak Pondoh Organik Ledoknongko, Dusun Ledoknongko, Desa Bangunkerto, Kecamatan Turi, Kabupaten Sleman, Provinsi Daerah Istimewa Yogyakarta. Lokasi ini berjarak sekitar $20 \mathrm{~km}$ dari pusat kota Yogyakarta dan dapat ditempuh menggunakan kendaraan pribadi.
Dalam penelitian ini akan membahas mengenai wisatawan di Wisata Agro Salak Pondoh Organik Ledoknongko dan bauran pemasaran produk salak pondoh di Wisata Agro Salak Pondoh Organik Ledoknongko. Ruang lingkup bahasan penelitian ini adalah Profil Wisatawan di WASPOL (Jumlah kunjungan wisatawan, tujuan kunjungan wisatawan, Kegiatan di WASPOL) dan Bauran pemasaran produk Salak Pondoh (produk, harga, distribusi, promosi, sarana fisik, orang, proses yang ada di WASPOL).

Jenis data yang digunakan dalam penelitian ini adalah jenis data kualitatif (Moleong, 1998) dan data kuantitatif (Sugiyono, 2010). Sumber data yang digunakan adalah primer (Sekaran dan Bougie, 2017) dan Sekunder (Sekaran dan Bougie, 2017). Teknik pengumpulan data dilakukan dengan observasi dan wawancara (Suryawan, dkk., 2017). Teknik penentuan informan yang digunakan adalah teknik purposive sampling (Sugiyono, 2010). Teknik analisis data menggunakan teknik analisis data kualitatif (Miles dan Huberman, 1994).

\section{HASIL DAN PEMBAHASAN \\ 4.1 Profil Wisatawan di Wisata Agro Salak Pondoh Organik Ledoknongko}

Profil wisatawan yang berkunjung wisatawan di agrowisata Ledoknongko dapat dilihat pada Tabel 1 dibawah.

TABEL 1. DATA JUMLAH PENGUNJUNG TAHUN 2015-2017

\begin{tabular}{cccc} 
Tahun & $\begin{array}{c}\text { Wisatawan } \\
\text { Nusantara } \\
\text { (orang) }\end{array}$ & $\begin{array}{c}\text { Wisatawan } \\
\text { Mancanegara } \\
\text { (orang) }\end{array}$ & $\begin{array}{c}\text { Jumlah } \\
\text { (orang) }\end{array}$ \\
\hline 2015 & 3.451 & 42 & 3.493 \\
\hline 2016 & 2.473 & 50 & 2.523 \\
\hline 2017 & 1.278 & 0 & 1.278 \\
\hline Total & 7.202 & 92 & 7.294 \\
\hline \multicolumn{4}{c}{ Sumber: Kelompok Tani “Si Cantik” (2018) }
\end{tabular}


Pihak pengelola mengakui adanya penurunan tingkat kunjungan wisatawan, dari tahun 2015 ke tahun 2016 mengalami penurunan sebesar 72\%, dari tahun 2016 ke tahun 2017 mengalami penurunan sebesar 50\%, karena itu, pada awal tahun 2018 pengelola menggencarkan kerja sama dengan travel agent untuk menarik minat kunjungan wisatawan terutama wisatawan mancanegara. Selain itu pihak pengelola juga lebih memfokuskan perhatiannya kepada ekspor buah salak ke beberapa negara seperti China dan Australia dibandingkan meningkatkan kunjungan wisatawan. Pengelola kelompok tani si cantik Misroji menyampaikan:

"Wisatawan yang berkunjung ke Wisata Agro Salak Pondoh Organik Ledoknongko memiliki tujuan yang sama yaitu untuk melakukan penelitian atau pembelajaran"

Hal ini dikarenakan banyaknya peneliti dari berbagai Universitas dan sekolah-sekolah yang ada di Indonesia datang untuk meneliti di WASPOL. Para petani yang terdapat di dalam Kelompok Tani Si Cantik akan memberikan pengetahuan tentang asal usul buah salak kemudian wisatawan akan diajak untuk belajar mengenai proses penanaman bibit salak yang baik dan secara organik, dan wisatawan bebas memetik buah salak dan bisa makan ditempat serta wisatawan juga akan diperlihatkan cara pengolahan buah salak menjadi beberapa produk seperti manisan salak, geplak salak, dan krasikan salak yang masih diolah dengan cara tradisional dan bertempat di rumah-rumah warga. Untuk mendapatkan pengalaman dan wawasan menarik tersebut, wisatawan cukup membayar Rp. 10.000, sedangkan jika wisatawan masuk hanya ingin berswa foto cukup membayar Rp. 3.000.

\subsection{Bauran Pemasaran Wisata Agro Salak Pondoh Organik Ledoknongko}

Pengelola WASPOL melaksanakan pemasaran dengan tahapan-tahapan dengan baik, dari perencanaan hingga proses eksekusi. Selain mengembangkan salak dengan sistem penanaman organik, kelompok tani juga mengembangkan berbagai produk olahan yang bahan utamanya ialah salak dari kebun mereka sendiri. Produk olahan ini memanfaatkan rumah para pengelola sekaligus meminimalisir biaya pengeluaran. Hal ini tentunya menjadi menarik sekaligus efesien dalam proses pengolahan, para petani juga mendapatkan alat produksi dari pengelola menggunakan uang kas bulanan. Walaupun dikerjakan dari rumah masing-masing, namun produk yang dihasilkan dapat menjadi keuntungan bagi WASPOL. Produk-produk milik WASPOL ini sudah memiliki brand sendiri, selain itu produk ini juga dikemas dengan sangat rapi, dan memiliki sertifikat halal dari LP-POM MUI serta telah memiliki ijin dari Dinas Kesehatan Kabupaten Sleman.

Berikut Bauran Pemasaran Salak Pondoh Organik kelompok tani "Si Cantik" berdasarkan Bauran Pemasaran menurut Kotler dan Amstrong (2012:62):

\section{Produk (product)}

Wisatawan yang datang untuk melakukan penelitian juga sudah disiapkan tour guide oleh pengelola untuk menjelaskan mengenai budidaya salak pondoh, tidak sampai di situ, wisatawan juga bisa menikmati salak pondoh di tempat.

Produk yang dihasilkan oleh WASPOL ini beragam. Mulai dari yang masih berbentuk buah segar hingga berbagai macam olahan buah salak. Bahkan Buah Salak Pondoh organiknya mampu menembus pasar internasional, seperti China, Singapura, Kamboja dan Australia. Sedangkan produk olahan salaknya bermacam-macam, yang hanya di jual di toko oleh-oleh khas Yogyakarta. Berikut beberapa produk olahan salak yang dikembangkan oleh WASPOL:

\section{a) Manisan Salak Pondoh "Sarisa"}

Manisan Salak Pondoh merupakan salah satu bentuk olahan salak yang dibuat dengan cara merebus salak yang telah dipotong-potong ke dalam larutan gula. Manisan merupakan salah satu metode pengawetan buah yang terbilang tua.

b) Geplak Salak Panggang "Mak Yati”

Geplak Salak Panggang merupakan makanan khas Kabupaten Sleman yang berbahan dasar salak panggang dan dicampur dengan gula pasir atau gula jawa dan kelapa parut. 
c) Krasikan Salak "Mak Yati”

Krasikan salak merupakan sebuah jajanan tradisional yang mirip dengan jenang atau dodol. Namun yang membedakan ialah jenang atau dodol memiliki tekstur yang lembut dan kenyal sedangkan krasikan memiliki tekstur yang sedikit agak kasar. Krasikan dibuat dengan beras ketan yang sudah di sangrai dan dicampur dengan kelapa parut dan salak parut kemudian dicampur dengan santan dan gula yang dimasak dan diaduk sampai padat.

\section{Harga (price)}

Harga untuk Buah Salak Organik yang di ekspor ke luar negeri seperti China, Singapura, Kamboja ataupun Australia tentu berbeda dengan harga buah di pasar lokal. Harga buah salak yang di ekspor seharga Rp.50.000/Kg. Untuk produk olahan serta buah dalam kemasan yang dijual di area perkebunan sangat terjangkau, untuk satu keranjang buah salak dijual Rp.20.000, untuk produk Geplak dan Krasikan dijual seharga Rp.15.000 per bungkusnya, dan untuk manisan "Sarisa" dijual seharga Rp.25.000 per kardus.

\section{Saluran Distribusi (place)}

Penyaluran produk olahan salak semua dilakukan oleh anggota WASPOL sendiri. Produk-produk olahan ini selain dijual langsung di lokasi WASPOL juga dijual keluar Desa Bangunkerto dengan cara dijual di beberapa toko oleh-oleh khas Yogyakarta. Sedangkan untuk buahnya diekspor 1 ton dalam 1 minggu ke negara seperti China, Singapura, Kamboja dan Australia yang bisa di dapatkan di beberapa supermarket negara tersebut dan sisanya akan dijual ke pasar tradisional dalam negeri seperti di Aceh, Pekanbaru, Palembang, Bali dan beberapa daerah lainnya.

\section{Promosi (promotion)}

Promosi mengenai produk-produk hasil perkebunan di Wisata Agro Salak Pondoh Organik Ledoknongko dilakukan melalui berbagai cara, yaitu dengan melakukan promosi melalui blog resmi, kemudian dengan cara bekerja sama dengan banyak agen perjalanan dan berfokus mengenalkan produk salak kepada para mahasiswa atau yang masih berada di tingkat SMA, SMP, ataupun SD. Dengan cara itu para pelajar akan tertarik untuk melakukan penelitian di WASPOL dan juga generasi-generasi berikutnya akan sering melaksanakan penelitian di WASPOL.

\section{Bukti Fisik (physical evidence)}

Perkebunan salak ini ditata serapi mungkin, semua pohon salak ditanam dengan jarak yang sama antar pohonnya, selain itu jarak yang dibuat juga cukup lebar sehingga dapat dilewati oleh wisatawan tanpa takut akan terkena duri pohon salak. Kebersihan di lingkungan WASPOL ini juga bersih dari sampah. Namun sangat disayangkan jalanan di Wisata Agro ini sedikit rusak beberapa bagian aspal jalan terlihat berlubang. Selain itu Wisata Agro Salak Pondoh Organik Ledoknongko juga masih tidak memiliki fasilitas pendukung seperti tempat parkir, toilet, serta bangunan yang dikhususkan untuk tempat jual beli oleholeh.

\section{Orang (people)}

Semua yang menjalankan aktivitas budi daya dan pemasaran salak merupakan orang yang berasal dari Dusun Ledoknongko. Para laki-laki di dusun ini yang bertanggung jawab dengan kualitas dari buah salak. Sedangkan kaum perempuan yang tergabung dalam UMKM Kusuma yang bertanggung jawab dengan berbagai olahan produk salak. Selain itu, dalam proses transaksi, para pedagang di Wisata Agro ini menawarkan barang-barang dagangannya dan melayani para pembeli dengan keramah-tamahan khas orang Yogyakarta.

\section{Proses (process)}

Proses pengembangan produk olahan salak di WASPOL memang masih berbasis rumahan. Segala proses produksi dilakukan di rumah masyarakat Dusun Ledoknongko. Segala keperluan produksi telah disiapkan oleh pengelola WASPOL menggunakan uang kas bulanan mereka. Selain itu dalam prosesnya kelompok tani bergotong royong untuk menciptakan suasana yang nyaman untuk seluruh anggota. 
Untuk mengatasi penurunan tingkat kunjungan wisatawan, pengelola WASPOL selain bekerja sama dengan travel agent juga memberikan suatu hal menarik kepada wisatawan seperti inovasi baru dalam paket wisata yang ditawarkan dan jika memungkinkan memberikan promo paket wisata, yang tentunya dapat menarik minat berkunjung wisatawan. WASPOL juga harus tetap mempertahankan kebersihan dan kerapihan seperti yang sudah terlaksana. Penambahan fasilitas seperti toilet umum, saung untuk tempat bersantai di kebun salak, serta penunjuk jalan menuju ke WASPOL harus dilakukan. Apabila memungkinkan sebaiknya membuat website yang khusus menjelaskan tentang WASPOL dan paket wisata yang ada. Selain itu, pendekatan kepada calon wisatawan baik domestik maupun mancanegara, dapat dilakukan melalui media sosial yang belum dibuat. Oleh karena itu, perlu dibuat media sosial seperti Facebook, Instagram, Twitter, Youtube. Setelah media sosial dibuat, pengelola memposting setiap hari tentang kegiatan yang sedang dilakukan. Jika berkenan, dapat bekerjasama dengan pengguna sosial media dengan jumlah follower minimal 1.000 untuk mempromosikan WASPOL dan setelah itu memberikan reward sebagai bentuk kerjasama. Dengan cara seperti itu, akan semakin banyak orang yang mengetahui dan ingin datang ke WASPOL.

\section{SIMPULAN}

Berdasarkan pokok permasalahan yang dibahas dalam penelitian, dapat ditarik simpulan, yaitu profil wisatawan yang berkunjung ke WASPOL memiliki tujuan yang sama yaitu untuk melakukan penelitian, hal ini karena adanya peneliti dari berbagai Universitas dan sekolah-sekolah yang ada di Indonesia. Pengunjung juga akan diajarkan cara budi daya salak pondoh oleh para petani dan bisa langsung memetik dan makan buah salak. Tingkat kunjungan wisatawan mengalami penurunan, dari tahun 2015 sebesar 3.493 orang turun menjadi 2.523 orang pada tahun 2016 dengan persentase penurunan sebesar $72 \%$, sedangkan pada tahun 2017 sebesar 1.278 orang dengan persentase penurunan sebesar 50\%. Menurunnya tingkat kunjungan wisatawan dari tahun 2015-2017 karena WASPOL lebih fokus kepada ekspor buah salak pondoh.

Hasil analisis bauran pemasaran di WASPOL adalah dimana WASPOL mengekspor Salak Pondoh ke berbagai negara seperti China, Australia, dan Kamboja sedangkan produk olahan salak hanya dijual di toko oleh-oleh khas Yogyakarta. Harga salak yang diekspor sebesar Rp. 50.000/Kg, sedangkan untuk buah salak yang dijual di area perkebunan seharga Rp. 20.000 per keranjang. Proses produksi Salak Pondoh dilakukan di rumah para kelompok tani dan semua yang menjalankan aktivitas budi daya dan pemasaran salak adalah orang yang berasal dari Dusun Ledoknongko. Perkebunan salak ditata dengan rapi dan bersih dari sampah. WASPOL melakukan promosi melalui blog resmi mereka yaitu sicantikledoknongko.blogspot.com.

\section{DAFTAR PUSTAKA}

Budiwinarmo, S. dan Cecep, T. S. (2014). Hak Indikasi Geografis terhadap Salak Pondoh di Kabupaten Sleman sebagai Upaya Perlindungan Hak Kekayaan Intelektual atas Produk Lokal. Cakrawala Hukum: Jurnal Ilmiah Vol IX No. 2

Hibran, S. (2016). Kolaborasi Wisata Dan Pertanian. Medan: Bisnis Indonesia.

Kotler, P. dan Armstrong, G. (2012). PrinsipPrinsip Pemasaran. In: Yasin, N. M., Ariffin, A. A. M. dan Ghaz. $8^{\text {th }}$ edition. Jakarta: Erlangga.

Mahagangga, I Gusti Agung Oka., Suryawan, Ida Bagus. Anom, I Putu dan Kusuma Negara, I Made. 2019. Evolusi Pariwisata Di Indonesia, Turismemorfosis di Kabupaten Badung, kabupaten Banyuwangi dan kabupaten Luwu Timur. Denpasar: Cakra Media Utama. https://www.researchgate.net/publicati on/335380603_Evolusi_Pariwisata_Di_I ndonesia_Turismemorfosis_di_Kabupate n_Badung_Kabupaten_Banyuwangi_dan_ Kabupaten_Luwu_Timur_Penerbit_Cakra _Media_Utama/citations.

Miles, M. B. dan Huberman, A. M. (1994). Qualitative Data Analysis. California: Sage. (Online). Available from: https://psycnet.apa.org 
Moleong, L. J. (1998). Metodologi Penelitian. Bandung: PT Remaja Rosda Karya.

Sekaran, U. dan Bougie, R. (2017). Metodologi Penelitian Untuk Bisnis. Jakarta: Salemba Empat.

Sugiyono. (2010). Metode Penelitian Pendidikan Pendekatan Kuantitatif, Kualitatif, dan R\&D. Bandung: Alfabeta.

Suryawan, Ida Bagus dan Mahagangga, I Gusti Agung Oka. 2017. Penelitian Lapangan 1. Denpasar: Cakra Press dan Fakultas Pariwisata Univeristas Udayana

Wardani, I. K. (2008). Model Pengelolaan Desa Wisata Perkebunan Salak Pondoh Kembangarum, Donokerto, Turi, Sleman, Yogyakarta. Surakarta: UNS - FSSR.

Sumber Internet Lainnya:

Http://kemenpar.go.id/asp/detil.asp?c=38\&id $=1120$ (diakses pada 25 April 2018 pukul 21.04 WITA)

Http://desawisatakotagede.blogspot.co.id/201 6/01/teori-desa-wisata.html?m=1

(diakses pada 21 Maret 2018 pukul 23.20 WITA) 